\title{
MOTIVASI ORANG TUA DALAM MEMASUKAN ANAKNYA DI PAUD PURNAMA DESA TAROPO KECAMATAN KILO KABUPATEN DOMPU
}

\author{
Rostinah \\ Masita \\ Institut Agama Islam Muhammadiyah Bima \\ Email: ssitasita321@gmail.com
}

Abstrak:

Penelitian ini berjudul Motivasi Orang Tua Dalam Memasukkan Anakknya di PAUD Purnama Desa Taropo Kecamatan Kilo Kabupaten Dompu. Tujuan penelitian ini adalah untuk mengetahui Motivasi Orang Tua Dalam Memasukkan Anakknya di PAUD Purnama Desa Taropo Kecamatan Kilo Kabupaten Dompu. Dengan Rumusan Masalah Bagaimanakan mengetahui Motivasi Orang Tua Dalam Memasukkan Anakknya di PAUD Purnama Desa Taropo Kecamatan Kilo Kabupaten Dompu.

Metode penelitian yang digunakan dalam penelitian ini penelitian kualitatif, dengan teknik yang digunakan dalam pengumpulan data yaitu: 1) Observasi, 2) Wawancara, dan 3) Dokumentasi. Instrumen penelitian menggunakan: 1) Observasi, 2) Wawancara dan 3) Dokumentasi. Dan Teknik Analisa Data menggunakan teori Milles dan Huberman dengan Teori Modifikasi, tahun 1992, dengan empat tahap yaitu: 1) Pengumpulan Data, 2) Penyajian Data, 3) Reduksi Data, dan 4) Verifikasi/Kesimpulan.

Hasil penelitiannya adalah sebagai berikut motivasi orang tua siswa untuk memasukan anaknya di PAUD Purnama, antara lain, (a) Karena tanggung jawab serta adanya kesadaran individu tentang kepentingan pendidikan dengan harapan menjadi anak yang sholeh dan sholehah, tertib ibadah, bisa membaca Al-Qur'an dan taat pada kedua orang tua, (b) pembelajaran di PAUD Purnama yang mengedepankan pendidikan agama, (c) kelengkapan sarana dan prasarana yang tersedia, (d) kerja sama yang baik antara sekolah dengan orang 
tua tentang model pengajaran nilai-nilai agama yang diberikan guru pada anak, (e) karena kualitas tenaga pengajarnya juga.

\section{Keywords: Motivasi, Orang Tua, dan PAUD.}

\section{PENDAHULUAN}

Pendidikan hampir semua manusia didunia ini membutuhkannya. Pendidikan sangat penting bagi manusia. Pendidikan sangat penting bagi kesejahteraan hidup manusia. Tanpa pendidikan manusia hidupnya akan seperti hewan. Tanpa tahu arah, tanpa tahu aturan.

Pendidikan adalah usaha sadar dan terencana untuk mewujudkan suasana belajar dan proses pembelajaran agar peserta didik secara aktif mengembangkan potensi dirinya untuk memiliki kekuatan spiritual keagamaan, pengendalian diri, kepribadian, kecerdasan, akhlak mulia, serta keterampilan yang diperlukan dirinya, masyarakat, bangsa dan negara. ${ }^{1}$

Sejalan dengan tujuan pendidikan nasional tersebut, maka untuk mewujudkannya diperlukan motivasi orang tua dalam mendidik anak. Di dalam sebuah keluarga motivasi orang tua sangat penting bagi anak, terlebih lagi ketika anak memasuki usia sekolah dan usia menempuh pendidikan lanjutan.

Orang tua adalah guru pertama bagi anak, karena orang tualah yang pertama kali mendidik atau menanamkan pendidikan dasar kepada anak-anaknya. ${ }^{2}$ Motivasi merupakan syarat mutlak dalam belajar, oleh karena itu hendaknya orang tua senantiasa memotivasi anak agar lebih giat dalam belajar danberprestasi. Motivasi belajar dari orang tua merupakan salah satu bentuk nyata pentingnya peran orang tua terhadap pendidikan anak-anaknya. ${ }^{3}$

Motivasi orang tua dalam pendidikan merupakan sesuatu yang sangat penting dan menjadi salah satu faktor yang mempengaruhi

h. 52

${ }^{1}$ Fuad Ihsan, Dasar-DasarKependidikan, Penerbit: PT.RinekaCipta, Jakarta,

2Endang Dewi Saputri, Motivasi Orang tua Dalam Memilih Paud Ditinjau Dari Profil Lembaga Pendidikan, Skripsi" Pendidikan Guru Pendidikan Anak Usia Dini Fakultas Ilmu Pendidikan Universitas Negeri Semarang, 2016, h. 17. 
ketercapaian belajar anak usia dini (AUD). Motivasi orang tua juga merupakan salah satu faktor eksternal yang mempengaruhi kemaun dan prestasi belajar belajar anaknya. Dimana anak akan mampu memiliki motivasi belajar yang tinggi atau rendah dipengaruhi oleh motivasi dari orang tuanya.

Motivasi orang tua adalah motivasi untuk mendidik, mengasuh,dan melatih jasmani dan rohani mereka yang dilakukan dengan berlandaskan nilai baik dan terpuji bersumber dari Al-Qur'an dan Sunnah. ${ }^{4}$ Sebab, anak adalah anugerah dan amanah dari Allah SWT yang harus di pertanggung-jawabkan oleh setiap orang tua dalam berbagai aspek kehidupannya. Diantaranya bertanggung jawab dalam pendidikan, kesehatan, kasih sayang, perlindungan yang baik, dan berbagai aspek lainnya. ${ }^{5}$

Pendidikan perlu dilihat sebagai suatu proses yang berterusan, berkembang, dan serentak dengan perkembangan individu seorang anak yang mempelajari apa saja yang ada di lingkungannya. Dengan kemahiran yang diperolehnya anak akan mengaplikasikannya dalam konteks yang bermacam-macam dalam hidup kesehariannya di saat itu ataupun sebagai persiapan untuk kehidupannya dimasa yang akan datang.

Motivasi orang tua dalam pendidikan anaknya dapat dipengaruhi oleh berbagai faktor; faktor penguatan nilai-nilai ketauhidan, dan dapat meningkatkan kemampuan membaca serta dapat merubah karakter anak. Terdapat dua faktor yang membuat seseorang termotivasi untuk belajar, yaitu; (1) Faktor Internal, terbentuk karena kesadaran diri atas pemahaman orang tua betapa pentingnya pendidikan bagi anaknya sehingga dengan memasukan anaknya dalam pendidikan dapat mengembangkan dirinya dan bekal untuk menjalani kehidupan, (2) faktor eksternal, berupa rangsangan dari luar, yaitu dari orang lain atau lingkungan disekitarnya yang dapat mempengaruhi motiviasi kita sehingga mendorong anak dalam menempuh pendidikan formal. 6

Agar hal tersebut dapat dicapai, dibutuhkan dukungan orang tua serta merangsang pendidikan di rumah sesuai kebutuhan anak. Selain

4Dewi Rizka, Motivasi Orang Tua Memilih Sekolah Berbasis Agama Islam, Skripsi", Universitas Negeri Yogyakarta, 2015, h. 22.

${ }^{5}$ Hendi, dkk, Pengantar Studi Sosiolog Keluarga, Penerbit: CV PustakaSetia, Bandung, ,2000, h. 41

6Fuad Ihsan, Dasar-Dasar. 35 
anak menempuh pendidikan disekolah, orang tua juga dapat berperan sebagai guru dirumah. Orang tua dapat menjadi guru yang efektif karena mereka banyak mengetahui tentang apa yang diperkirakan sedang diajarkan oleh sekolah, serta apa yang perlu mereka lakukan sebagai lanjutannya dirumah. Orang tua juga dapat membantu anak mengerjakan pekerjaan rumah dan menyediakan dukungan stimulasi kognitif di rumah.

Sangat penting bagi orang tua untuk menjadi pengemudi dalam proses belajar anak, menyediakan bimbingan dan informasi di seluruh waktu agar anak-anak tetap berada dalam jalurnya dan tidak teralihkan dari potensi akademik mereka. Pentingnya keterlibatan orang tua dalam memotivasi proses pendidikan anak yaitu: (1) Menjadi panutan bagi anak, (2) Memperhatikan minat atau kesukaan anak, (3) Terlibat dalam cara belajar anak, (4) Berlatih apa yang dipelajari anak di sekolah, (5) Menyediakan waktu untuk membaca bersama, (6) Hubungkan pelajaran anak dengan dunia nyata, (7) Hubungkan pelajaran anak dengan kondisi dunia, (8) Bantu anak untuk bertanggung jawab dengan pelajarannya, (9) Jangan membebani jadwal anak. ${ }^{7}$

Mengenai pendidikan anak-anaknya, orangtua perluadanya kerjasama dengan pihak lain seperti halnya pihak sekolah. Dengan adanya kerjasama dan rasa saling percaya antara orang tua dan pihak sekolah akan anak terciptanya pendidikan anak yang maksimal dan tujuan serta harapan orang tua akan pendidikan anak akan tercapai dalam hal pendidikan anak parsekolah/sebelum memasuki jenjang pendidikan dasar. Kerja sama antara orang tua dengan lembaga pendidikan, memberikan dampak positif bagi orang lain, sehingga orang tua akan terlebih dahulu mengenali provil sekolah serta visi dan misi yang dijalangkan dalam pendidikan tersebut. ${ }^{8}$

Berdasarkan paparan tersebut terlihat bahwa melalui motivasi orang tua yang intensif terhadap tumbuh kembang anak, banyak pengaruh positif yang diperoleh anak. Sebaliknya, kurangnya motivasi orang tua akan mengakibatkan berbagai pengaruh buruk seperti menurunnya prestasi, meningkatnya perilaku anti sosial, dan hubungan yang kurang baik dengan guru dan orang tua. Satu sisi, sekolah sebagai

${ }^{7}$ Munardji, Ilmu Pendidikan Islam, Penerbit: PT Bina Ilmu, Jakarta, 2004, h. 131

8Mansur, Pendidikan Anak Usia Dini dalam Islam, Cetakan Ke-V, Penerbit:Pustaka Pelajar:Yogyakarta,2014, h. 28. 
mitra orang tua dalam pendidikan anak membutuhkan kerja sama aktif dengan orang tua murid. Karena keterlibatan orang tua dalam pendidikan anak merupakan kerja sama jangka panjang.

Motivasi adalah dorongan atau perangsang yang membuat seseorang melakukan pekerjaan yang diinginkannya dengan rela tanpa merasa terpaksa sehingga pekerjaan yang dilakukan dapat berjalan dengan baik atau menghasilkan sesuatu yang memuaskan. Dengan tujuan motivasi adalah sebagai berikut:

1. Mendorong gairah dan semangat kerjaorang lain.

2. Meningkatkan moral dankepuasan kerjaorang lain.

3. Meningkatkan produktivitas kerjaorang lain.

4. Mempertahankan loyalitas dan kestabilan orang lain.

5. Meningkatkan kedisiplinan dan menurunkantingkat absensi orang lain.

6. Mengefektifkan pengadaan orang lain.

7. Menciptakan suasanadan hubungan kerjayangbaik.

8. Meningkatkan kreativitas dan partisipasi orang lain.

9. Meningkatkan tingkat kesejahteraan orang lain.

10. Mempertinggi rasatanggungjawab orang lain terhadap tugastugasnya. ${ }^{9}$

Peranan orang tua terhadap pendidikan anak, antara lain:

1. Mendidik pada masa kanak-kanak

Keluargalah anak didik mulai mengenal hidupnya. Lembaga pendidikan keluarga memberikan pengalaman pertama dalam perkembangan pribadi anak, suasana pendidikan keluarga sangat penting diperhatikan oleh orang tua.

2. Memberikan pendidikan tauhid

Pendidikan Islam dalam keluarga harus memperhatikan pendidikan akidah Islamiyah, dimana akidah itu merupakan inti dasar keimanan seseorang yang harus ditanamkian kepada anak sejak dini. ${ }^{10}$ Sebagaimana Firman Allah SWT dalam QS Lukman(31) ayat 13 sebagai berikut:

h. $21-22$

${ }^{9}$ AlisufSabri,PengantarIlmuPendidikan, Penerbit: UINJakartaPress,Jakarta, 2005,

${ }^{10}$ Mansur, Pendidikan Anak Usia Dini Dalam Islam, (Yogyakarta, Pustaka Pelajara, 2015), 325 


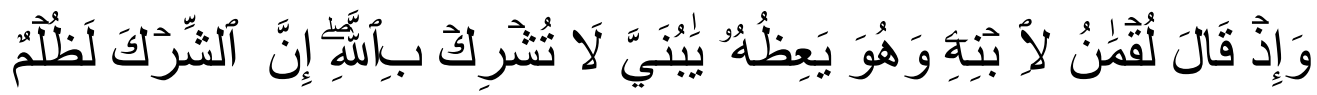

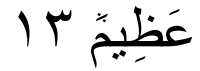

Artinya :

Dan (ingatlah) ketika luqman berkata kepada anaknya, di waktu ia memberi pelajaran kepadanya, "Hai anakku, jangalah kamu mempersekutukan Allah, sesungguhnya mempersekutukan Allah benar-benar kezholiman besar(QS Lukman(31): 13). ${ }^{11}$

1. Menjamin kehidupan sosial anak.

Ada hubungan darah antara orang tua dengan anak dan hubungan tersebut didasarkan atas rasa cinta kasih sayang yang murni, kehidupan emosional merupakan salah satu faktor yang terpenting didalam membentuk pribadi seseorang.

2. Menanamkan pendidikan Ibadah

Orang tua memiliki kewajiban untuk menanmkan pendidikkan ahklakul karimah pada anak-anaknya yang dapat membahagiakan di alam kehidupan dunia dan akhirat. ${ }^{12}$

Orang tua haru selalu mengajak anak untuk mendirikan sholat, sebab sholat atau ibadah merupakan kewajiban bagi setiap manusia. Sebagaimana firman Allah SWT dalam Al-Qur'an surat Lukman (31) ayat 17 sebagai berikut:

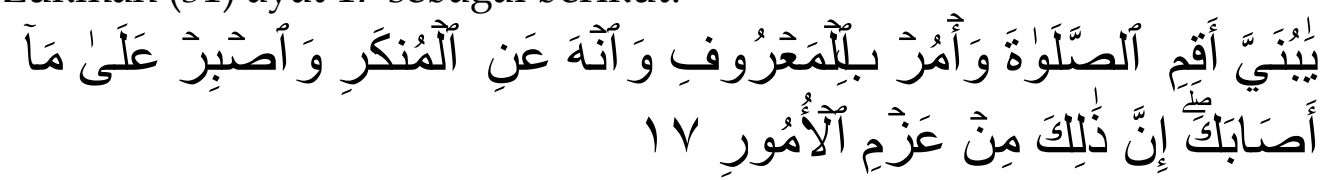

Artinya:

Hai anakku, dirikanlah shalat dan suruhlah (manusia)mengerjakan yang baik dan cegahlah (mereka) dari perbuatan yang mungkar dan bersabarlah terhadap apa yang menimpa kamu. Sesungguhnya yang demikian itu termasuk hal-hal yang diwajibkan (oleh Allah). ${ }^{13}$

Dalam ayat yang lain dijelaskan bahwa, Allah SWT menciptkan manusia didunia ini, tidak lain hanya untuk beribadah kepada Allah SWT. Allah SWTdalam Al-Qur'an surat Q.S AdzDzaariyaat ayat (51:56), berfirman:

\footnotetext{
${ }^{11}$ Q.S Lukman (31:13).

${ }^{12}$ Ibid., 324

${ }^{13}$ Q.S. Lukman (31:17).
} 


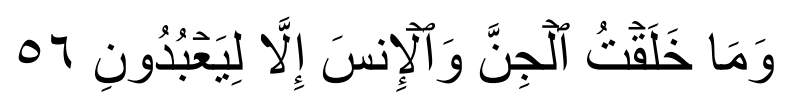

Artinya :

Dan tidaklah Aku ciptakan Jin dan Manusia kecuali untuk beribadah kepadaku" (Q.S Adz-Dzaariyaat ayat (51:56). ${ }^{14}$

3. Memberikan dasar pendidikan sosial.

Keluarga merupakan basis yang sangat penting dalam peletakan dasar-dasar pendidikan sosial anak, sebab pada dasarnya keluarga merupakan lembaga sosial resmi yang minimal terdiri dari ayah, ibu, dan anak-anak, perkembangan benih-benih kesadaran sosial pada anak-anak dapat dipupuk sedini mungkin terutama lewat kehidupan keluarga yang penuh rasa tolong-menolong, gotong-royong secara kekeluargaan, menolong saudara atau tetangga sakit, bersama-sama menjaga ketertiban, kedamaian, kebersihan dan keserasian dalam menjaga hal. ${ }^{15}$

Observasi awal yang dilakukan oleh peneliti terhadap masyarakat yang terdiri dari orang tua anak usia dini (AUD) yaitu seperti ibu yanti yang beralamat di Desa Taropo, bahwa tentang bagaimana memotivasi orang tua dalam memasukan anaknya di Paud Purnama Desa Taropo Kecamatan Kilo Kabupaten Dompu, menyatakan bahwa yang mendorong atau yang memotivasinya karena dipengaruhi oleh faktor internal orang tua anak usia dini (AUD) yaitu adanya kesadaran terhadap kebutuhan pendidikan anaknya, sedangkan faktor eksternalnya adalah karena; (1) karena visi, misi serta tujuan sekolah yaitu fokus pada penanaman pendidikan agama, seperti menghafal ayat-ayat pendek, menguasai tata cara bacaan Al-Qur,an secara baik dan benar, (2) prestasi guru yaitu guru dapat dijadikan contoh yang baik bagi anak-anaknya, seperti guru-guru melakukan sholat dhuha dilakukan bersama anakanak di PAUDtersebut. ${ }^{16}$

Ada beberapa hal yang dapat memotivasi orang tua dalam memilih sekolah, antara lain; (1) sarana dan prasarana yang lengkap yang dapat mendukung proses belajar anak, (2) Pemberian perhatian

\footnotetext{
${ }^{14}$ Q.S Adz-Dzaariyaat ayat (51:56)

${ }^{15}$ Hasbullah, Dasar-Dasar Ilmu Pendidikan, Penerbit: PT. Raja Grafindo Persada,

${ }^{16}$ Observasi, Dompu, 8 Juni 2019
} Jakarta, 2001, h. 88. 
yang tinggi terhadap anak, misalnya dengan menuruti kemauannya, mengontrol kelakuannya, dan memberikan rasa perhatian yang lebih, (3) Pencurahan rasa cinta dan kasih sayang, yaitu dengan berucap lemah lembut, berbuat yang menyenangkan dan selalu berusaha menyelipkan nilai pendidikan pada semua tingkah laku kita, (4) Memberikan contoh kebiasaan hidup yang bermanfaat bagi anak, yang diharapkan akan menumbuhkan sikap kemandirian anak dalam melaksanakan aktifitasnya sehari-hari, (5) Menanamkan dasar pendidikan moral dan memberikan dasar pendidikan sosial serta peletakkan dasar-dasar keagamaan. ${ }^{17}$

Keterlibatan orang tua juda dalam memasukannya, antara lain; (1) Ikut dalam forum sekolah, seperti menemani anak, (2) memberikan dukungan serta menyemangati anak saat belajar, (3) Berkomunikasi dengan guru secara proaktif, (4) Mengobrol dengan anak tentang kegiatan mereka sehari-hari di sekolah. ${ }^{18}$

Berdasarkan latar belakang diatas, maka peneliti tertarik mengadakan penelitian dengan mengangkat judul, "Motivasi Orang Tua Dalam Memasukan Anaknya di PAUD Purnama Desa Taropo Kec. Kilo Kab.

\section{METODE PENELITIAN}

Jenis penelitian adalah penelitian kualitatif, dengan teknik yang digunakan dalam pengumpulan data yaitu: 1)Observasi, 2) Wawancara, dan 3) Dokumentasi. Instrumen penelitian menggunakan: 1) Observasi, 2) Wawancara dan 3) Dokumentasi. Dan Teknik Analisa Data menggunakan teori Milles dan Huberman dengan Teori Modifikasi, tahun 1992, dengan empat tahap yaitu: 1) Pengumpulan Data, 2) Penyajian Data, 3) Reduksi Data, dan 4) Verifikasi/Kesimpulan.

\section{HASIL PENELITIAN}

1) Motivasiorang tua dalam memasukkan anaknya di PAUD Purnama Desa Taropo Kecamatan Kilo Kabupaten Dompu.

Manusia adalah makhluk individu dan sosial. Manusia memang bisa bersifat individual tetapi manusia hidup tidak akan

\footnotetext{
${ }^{17}$ Dewi Rizka, Motivasi Orang Tua Memilih Sekolah Berbasis Agama Islam,Skripsi, Universitas Negeri Yogyakarta, 2015, h. 22.

${ }^{18}$ EniLutfiati, Peranan Orang Tua dalam PembinaanKarakter AnakUsiaDini MelaluiPembiasaan DiKelompok BermainHarapan Bunda Purwokerto, Skripsi, FakultasTarbiyahDanIlmuKeguruan IAIN Purwekorto, 2016, h. 2-3.
} 
terlepas dari orang lain. Manusia pertama hidup di dalam lingkungan keluarga dan interaksi pertama dilakukan dengan orang tua yang telah mengandung, melahirkan, dan merawat serta membimbing dan mendidiknya.Dalam keluarga yang mendapat sorotan pertama adalah orang tua.Peran orang tua sangatlah besar dan sentral bagi anakanaknya.

Dalam proses pendidikan orang tua turut bertanggung jawab terhadap kelangsungan hidup anak. Orang tua seharusnya memahami bahwa merekalah sebagai penanggung jawab utama dalam pendidikan putra-putrinya.secara umum, berhasil tidaknya pendidikan seorang anak biasanya dihubungkan dengan motivasi orang tua. Dorongan atau motivasi orang tua menjadi tolok ukur bagaimana orang tua harus memutuskan suatu hal yang cocok untuk anak.

Hasil wawancara dengan Yanti selaku orang tua peserta didik menyatakan bahwa yang memotivasi kami sebagai orang tua dalam memasukan anaknya di PAUD Purnama Desa Taropo Kecamatan Kilo Kabupaten Dompu, karena sarana dan pra-sarana PAUD yang tersedia, lalu:

"Yang paling besar adalah karena tanggung jawab orang tua. Disamping itu, yang memotivasi bagi kami sebagai orang tua dalam memasukan anak kami di PAUD Purnama Desa Taropo Kecamatan Kilo Kabupaten Dompu, antara lain; pembelajaran di PAUD Purnama yang mengedepankan pendidikan agama, kelengkapan sarana dan prasarana yang tersedia dan kerja sama sekolah dengan orang tua tentang model pengajaran nilai-nilai agama yang diberikan guru pada anak, dan karena kualitas tenaga pengajarnya juga" ${ }^{19}$

Sedangkan menurut Nurma selaku orang tua peserta didik yang lain bahwa yang memotivasi kami sebagai orang tua dalam memasukan anaknya di PAUD Purnama Desa Taropo Kecamatan Kilo Kabupaten Dompu adalah:

"Karena tenaga pengajar yang cukup lumayan banyak serta kualitas penyelenggaraan pendidikan agama yang bagus, "Iya.. yang memotivasi sebagai orang tua sehingga memasukan anak di PAUD Purnama Desa Taropo Kecamatan Kilo Kabupaten 
Dompu karena keadaan sekolah itu sendiri yaitu tanggung jawab orang tua, ditambah lagi dengan penyelengaraan pengajaran yang berbasis agama Islam. Hal lain, adalah karena sarana dan prasarana sekolah yang tersedia sehingga dapat membantu anak kami dalam proses pembelajaran". ${ }^{20}$

Motivasi orang tua dalam memasukan anaknya di PAUD Purnama Desa Taropo Kecamatan Kilo Kabupaten Dompu sangat beragam. Seperti yang dikatakan oleh Ibu Hardianti selaku orang tua peserta didik dalam wawancara sebagai berikut;

"Yang memotivasi kami sebagai orang tua dalam memasukan anaknya di PAUD Purnama Desa Taropo Kecamatan Kilo Kabupaten Dompu sebenarnya juga karena kesadaran kami terhadap pentingnya pendidikan itu sendiridengan harapan menjadi anak yang sholeh dan sholehah, tertib ibadah, bisa membaca Al-Qur'an dan taat pada kedua orang tua. Disamping itu, karena faktor sekolah yang mengedepankan pembelajaran agama Islam, yaitu belajar sholat, dan belajar membaca $\mathrm{Al}$ Quran. Hal lain juga karena sarana dan prasarana yang disediakan oleh sekolah sehingga kegiatan pembelajaran tersebut dapat berjalan dengan baik, ditambah lagi dengan keadaan guru yang berkualitas pada bidang ilmunya masingmasing" 21

Sedangkan menurut Rahma selaku orang tua peserta didik menyatakan bahwa Motivasi orang tua dalam memasukan anaknya di PAUD Purnama Desa Taropo Kecamatan Kilo Kabupaten Dompu berikut:

"Sebagai sebenarnya dipengaruhi oleh kesadaran kami sebagai orang tua dan didukung oleh keadaan sekolah itu sendiri. Lalu setidaknya ada beberapa alasana atau motivasi tersendiri bagi kami sebagai orang tua yang dalam memasukan anak kami di PAUD Purnama Desa Taropo Kecamatan Kilo KabupatenDompu, antara lain; karena mengutamakan penanaman nilai dasar pendidikan yaitu nilai tauhid, moral dan memberikan dasar pendidikan sosial serta peletakkan dasardasar keagamaan, kelengkapan sarana dan prasarana yang

${ }^{20}$ Wawancara, NurmaOrang Tua Murid, PAUD Purnama, 3 Oktober 2019, pukul 09:50 wita.

${ }^{21}$ Wawancara, Hardianti Orang Tua Murid Taropo-kilo, 3 Oktober 2019, pukul 11:20 Wita. 
tersedia dan karena kualitas tenaga pengajarnya juga. Kami juga memiliki harapan bahwa anak kami menjadi anak yang sholeh dan sholehah, tertib ibadah, bisa membaca Al-Qur'an dan taat pada kedua orang tua" 22

Sedangkan wawancara dengan Ibu Arina, S.Pd.I selaku kepala sekolah PAUD Purnama, menyatakan bahwa:

"Yang memotivasi orang tua siswa memasukan anaknya untuk sekolah PAUD Purnama ini karena keadaan sekolah, diantaranya kualitas guru dan sarana prasarana yang tersedia. Tentu yang memotivasi orang tua memasukan anak di PAUD Purnama karena kualitas sekolah yang baik, biaya sekolah yang terjangkau, lokasi yang dekat dengan tempat tinggal dan akses yang mudah, sarana dan prasarana yang memadai. Disekolah ini juga menyelenggaran pendidikan yang berbasih Islami." 23

Sedangkan menurut Ibu Evi Novita Sari selaku guru PAUD Purnama menyatakan yang memotivasi orang tua siswa dalam memasukan anaknya di PAUD adalah:

"Yang memotivasi orang tua siswa dalam memasukan anaknya di PAUD Purnama, karena kualitas PAUD Purnama seperti keadaan guru yang selalu mengajarkan nilai-nilai agama, tentang baca $A l-Q u r^{\prime} a n$, dan praktek sholat. Sepengetahuan kami sebagai guru terutama dari hasil evaluasi, saran masukan bahwa Pembelajaran di PAUD Purnama ini mengedepankan pendidikan agama, kelengkapan sarana dan prasarana yang tersedia dan kerja sama sekolah dengan orang tua tentang model pengajaran nilai-nilai agama yang diberikan guru pada anak, dan karena kualitas tenaga pengajarnya juga. Hal tersebut dapat menarik perhatian orang tua di desa ini" 24

Jadi dari beberapa hasil wawancara dengan informan diatas dapat disimpulkan bahwa yang memotivasi orang tua siswa untuk memasukan anaknya di PAUD Purnama, antara lain, (a) Karena tanggung jawab serta adanya kesadaran individu tentang kepentingan pendidikan dengan harapan menjadi anak yang sholeh dan sholehah,

22Wawamcara, Rahma Orang Tua Murid Taropo-Kilo, 3 Oktober2019, Pukul 10:12 Wita.

${ }^{23}$ Wawancara, Arina, S.Pd.I kepala Sekolah PAUD Purnama, 4 Oktober 2019, pukul 09:19 Wita.

${ }^{24}$ Wawancara, Evi Novitasari Guru PAUD Purnama, 4 Oktober 2019, Pukul 10:23 Wita. 
tertib ibadah, bisa membaca Al-Qur'an dan taat pada kedua orang tua, (b) pembelajaran di PAUD Purnama yang mengedepankan pendidikan agama, (c) kelengkapan sarana dan prasarana yang tersedia, (d) kerja sama yang baik antara sekolah dengan orang tua tentang model pengajaran nilai-nilai agama yang diberikan guru pada anak, (e) karena kualitas tenaga pengajarnya juga.

\section{KESIMPULAN}

Berdasarkan pembahasan diatas dapat disimpulkan sebagai berikut bahwa motivasi orang tua siswa untuk memasukan anaknya di PAUD Purnama, antara lain, (a) Karena tanggung jawab serta adanya kesadaran individu tentang kepentingan pendidikan dengan harapan menjadi anak yang sholeh dan sholehah, tertib ibadah, bisa membaca AlQur'an dan taat pada kedua orang tua, (b) pembelajaran di PAUD Purnama yang mengedepankan pendidikan agama, (c) kelengkapan sarana dan prasarana yang tersedia, (d) kerja sama yang baik antara sekolah dengan orang tua tentang model pengajaran nilai-nilai agama yang diberikan guru pada anak, (e) karena kualitas tenaga pengajarnya juga.

\section{REFERENSI}

Ali Sufsabri, Pengantar Ilmu Pendidikan, Penerbit: UIN Jakarta Press,Jakarta, 2005.

Dewi Rizka, Motivasi Orang Tua Memilih Sekolah Berbasis Agama Islam, Skripsi", Universitas Negeri Yogyakarta, 2015.

Dewi Rizka, Motivasi Orang Tua Memilih Sekolah Berbasis Agama Islam,Skripsi, Universitas Negeri Yogyakarta, 2015.

Eni Lutfiati, Peranan Orang Tua dalam PembinaanKarakter AnakUsiaDiniMelaluiPembiasaan DiKelompok BermainHarapan Bunda Purwokerto, Skripsi, Fakultas Tarbiyah Dan Ilmu Keguruan IAIN Purwekorto, 2016.

Endang Dewi Saputri, Motivasi Orang tua Dalam Memilih Paud Ditinjau Dari

Profil Lembaga Pendidikan, Skripsi” Pendidikan Guru Pendidikan Anak Usia Dini Fakultas Ilmu Pendidikan Universitas Negeri Semarang, 2016 
Fuad Ihsan, Dasar-DasarKependidikan, Penerbit: PT.RinekaCipta, Jakarta, Hendi, dkk, Pengantar Studi Sosiolog Keluarga, Penerbit: CV PustakaSetia, Bandung,2000.

Munardji, Ilmu Pendidikan Islam, Penerbit: PT Bina Ilmu, Jakarta, 2004.

Mansur, Pendidikan Anak Usia Dini dalam Islam, Cetakan Ke-V, Penerbit:Pustaka Pelajar:Yogyakarta,2014.

Mansur, Pendidikan Anak Usia Dini Dalam Islam,Penerbit: Pustaka Pelajara, 2015, Yogyakarta

Hasbullah, Dasar-Dasar Ilmu Pendidikan, Penerbit: PT. Raja Grafindo Persada, Jakarta, 2001.

Observasi, Dompu, 8 Juni 2019

Wawancara, Yanti Orang Tua Murid, PAUD Purnama, 3 Oktober 2019, pukul 09:30 wita.

Wawancara, NurmaOrang Tua Murid, PAUD Purnama, 3 Oktober 2019, pukul 09:50 wita.

Wawancara, Hardianti Orang Tua Murid Taropo-kilo, 3 Oktober 2019, pukul 11:20 Wita.

Wawamcara, Rahma Orang Tua Murid Taropo-Kilo, 3 Oktober2019, Pukul 10:12 Wita.

Wawancara, Arina, S.Pd.I kepala Sekolah PAUD Purnama, 4 Oktober 2019, pukul 09:19 Wita.

Wawancara, Evi Novitasari Guru PAUD Purnama, 4 Oktober 2019, Pukul 10:23 Wita. 